Original Research Paper

\title{
Potensi Pengembangan Ekowisata Solusi Matapencaharian Berkelanjutan Masyarakat di Desa Ketapang Raya Lombok Timur
}

\author{
Abdul Syukur $^{1 *}$, Agil Al Idrus ${ }^{1}$, Lalu Zukifli ${ }^{1}$, Mahrus $^{1}$ \\ ${ }^{\text {I} P r o g r a m ~ S t u d i ~ P e n d i d i k a n ~ B i o l o g i, ~ F a k u l t a s ~ K e g u r u a n ~ d a n ~ I l m u ~ P e n d i d i k a n, ~ U n i v e r s i t a s ~ M a t a r a m, ~ M a t a r a m, ~ I n d o n e s i a ~}$
}

DOI: https://doi.org/10.29303/jpmpi.v3i2.575

Sitasi:. Syukur, A., Idrus, A. A., Zulkifli, L., \& Mahrus. (2020 Potensi Pengembangan Ekowisata Solusi Matapencaharian Berkelanjutan Masyarakat di Desa Ketapang Raya Lombok Timur. Jurnal Pengabdian Magister Pendidikan IPA, 3(2)

\section{Article history}

Received: 25 Oktober

Revised: 15 Nopember

Accepted: 30 Desember

*Corresponding Author: Abdul Syukur, Program Studi Pendidikan Biologi, Fakultas Keguruan dan Ilmu Pendidikan, Universitas Mataram, Mataram, Indonesia

Email: syukur_unram@ymail .com

\begin{abstract}
Desa Ketapang Raya meskipun merupakan desa pemekaran tatapi telah mulai mengembangakan parawisata yaitu wisata pantai. Keberadaan wisata pantai di Desa Ketapang Raya telah dirasakan manfaatnya oleh masyarakat sebagai sumber ekonomi baru. Dalam waku dua tahun aktivias parawisata cukup memberikan harapan yang ditandai oleh jumlah masyarakat yang matapencahirannya dari kegiatan para wisata. Desa Ketapang Raya yang merupakan desa pantai memiliki objek wisata selain wisata pantai. Namun demikian belum dikembangkan sebagai objek wisata. Oleh karena itu dibutuhkan fasilitasi agar potensi lingkungan dapat dikembangkan sebagai objek wisata. Pengembangan objek wisata selain wisata pantai tentunya dapat menjadi sumber matapencaharian masyarakat di Desa Ketapang Raya. Pengembangan ekowisata di Desa Desa Ketapang Raya solusi dari permasalahan kapasias pengelolaan yang bersumber dari kelompok masyarakat. Beberapa metode yang akan digunakan adalah Sosialisai, pelatihan dan Fokus Group diskusi. Pada tahap sosialisasi tim pada tahap ini Tim mensosialisaikan tema program pada pemerintah Desa, tokoh masyarakat dan stakehoulder lainnya. Metode yang digunakan adalah diskusi. Tujuan pada program sosialisai adalah untuk memperoleh pemahaman yang sama tentang pentingnya pengembangan ekowisata sebagai sumber matapencaharaian berkelanjutan masyarakat di Desa Ketapang Raya. Selain itu disampaikan luaran yang perlu dicapai dari tipa solusi permasalahan. Metode Pelatihan untuk pelatih (Training of Trainer), materi terdiri dari empat bagian yang terdiri dari: (a) langkah- langkah yaitu uraian yang menjelaskan langkah demi langkah yang dapat dilakukan oleh fasilitator dalam memfasilitasi kegiatan pelatihan pada tiap program, (b). bahan bacaan adalah materi bacaan yang dapat dijadikan referensi bagi fasilitator atau pelatih mengenai isi materi yang akan disampaikan dan (3) lembar kegiatan yang merupakan lembar aktivitas yang digunakan peserta dalam proses pembelajaran dan slide presentasi. 2. Fokus Group Diskusi (FGD) adalah metode yang digunakan berdasarkan relevansi tiap solusi, hal ini sangat penting untuk memperoleh informasi mengenai beberapa pertanyaan tentang bagaiamana dan mengapa kita butuhkan ekowisata sebagai sumber matapencaharian yang berkelanjutan bagi masyarakat di Desa Ketapang Raya. Selain itu dari program ini dihasilkan publikasi pada jurnal yang memiliki ISSN dan buku ekowisata desa yang memiliki ISBN.
\end{abstract}

Keywords: Potensi; Ekowisata; Matapencaharian; Ketapang Raya. 


\section{Pendahuluan}

Desa Ketapang Raya salah satu desa pantai dengan jumlah nelayan kecil sebesar $50 \%$ dari total jumlah penduduk sebanyak 4376 jiwa (Monografi Desa Ketapang Raya, 2017). Nelayan skala kecil ini telah mengembangkan budidaya untuk mengatasi masalah ekonomi keluarga, sebagai akibat dari hasil tangkapan ikan yang sudah tidak menentu. Menurut Idrus et al (2018) masyarakat Desa Keatapang Raya berasal dari berbagai Suku dan Ras yang tersebar diseluruh Wilayah Desa Keatapang Raya dan beragam bahasa antara lain, Bahasa Bajo, digunakan sebagai bahasa sehari-hari, Bahasa Sasak, Bahasa Bugis, Bahasa Mandar, Jawa dan Madura. Masyarakat yang majemuk, sebagian besar berasal dari Daerah Sulawesi Selatan yang dikenal dengan Pelaut, sehingga sebagian besar Penduduk Desa dengan mata pencaharian Nelayan. Jumlah rumah tangga $987 \mathrm{kk}$ dengan jumlah penduduk 3.579 jiwa yang terdiri dari, laki-laki 1.729 , perempuan 1.850. Penduduk cukup padat dan berkembang, tahun 2014 kepadatan 2.944 jiwa/km2, tahun 2015 kepadatan 2.982 jiwa/km2, dan tahun 2016 kepadatan 3.020 jiwa/km2.

Desa Ketapang Raya meskipun merupakan desa pemekaran tatapi telah mulai mengembangakan parawisata yaitu wisata pantai. Keberadaan wisata pantai di Desa Ketapang Raya telah dirasakan manfaatnya oleh masyarakat sebagai sumber ekonomi baru. Dalam waku dua tahun aktivias parawisata cukup memberikan harapan yang ditandai oleh jumlah masyarakat yang matapencahirannya dari kegiatan para wisata (KKN Unram, 2018). Desa Ketapang Raya yang merupakan desa pantai memiliki objek wisata selain wisata pantai. Namun demikian belum dikembangkan sebagai objek wisata. Oleh karena itu dibutuhkan fasilitasi agar potensi lingkungan dapat dikembangkan sebagai objek wisata. Pengembangan objek wisata selain wisata pantai tentunya dapat menjadi sumber matapencaharian masyarakat di Desa Ketapang Raya.

Bentuk paraiwisata yang dikembangkan di Desa Ketapang Raya adalah parawisata dengan konsep ekowisata. Hal ini tentu konsep ekowisata selain relevan dengan keberlanjutan fungsi lingkungan atau kelestarian lingkungan, juga adanya nilai pendidikan yang sangat penting bagi masyarakat dan pelaku wisata. Objekvitas dan rasionalitas dari program pemberdayaan masyarakat pesisir melalui pengembangan objek wisata baru berbasis ekowisata ini didasarkan atas beberapa hal yaitu: (1) aspek ekonomi nelayan atau masyarakat memiliki tambahan sumber pendapatan dari jasa wisata dan sarana pariwisata (2) aspek lingkungan, nelayan, masyarakat sekitar, maupun stake holder pariwisata akan menjaga kelestarian lingkungannya , (3) aspek sosial, antar masyarakat akan terbentuk sistem sosial yang lebih akomodatif dalam menjaga kerentanan sosial masyarakat dan (4) aspek manajemen, masyarakat dan pelaku pariwisata mampu mengelola tempat wisata yang berkelanjutan. Kegiatan pengabdian pada masyarakat ini dirancang secara sistematis dengan tujuan dan sasaran masyarakat dan mitra di Desa Keapang Raya. Selanjutnya manfaat dari kegiatan ini adalah tersosialisanya konsep ekowisata sebagai pilihan pengembangan ekonomi masyarakat Desa Ketapang Raya dan kelestarian lingkungan.

Desa Ketapang Raya dengan potensi pantai yang indah mulai mendapat perhatian dari para wisatawan sebagai lokasi wisata. Desa Ketapang Raya memiliki potensi wisata yang sangat banyak sesuai dengan potensi lingkungan. Beberapa potensi wisata di Desa Ketapang Raya adalah:

\section{Wisata Pantai Lungkak}

Pantai Lungkak terletak di Dusun Lungkak,

Desa Ketapang Raya, Kecamatan Keruak, Kabupaten Lombok Timur, Nusa Tenggara Barat. Pantai yang berpasir hitam ini cukup aktif sebaga tempat berlabuhnya perahu-perahu nelayan. Namun, karena pantai ini memiliki hamparan pasir yang landai dan indah, sehingga oleh kelompok pemuda yang menamakan diri sebagai kelompok pemuda sadar wisata (POKDARWIS) memiliki ide kreatif untuk menggali dan mengembangkan kawasan pantai ini sebagai obyek wisata pantai.

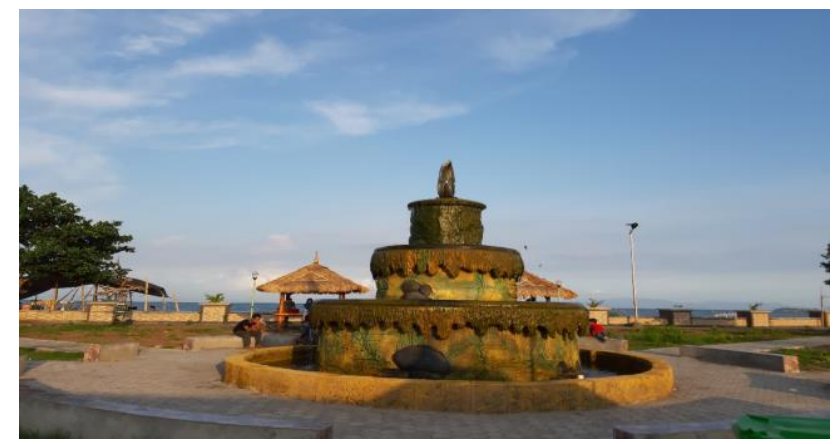



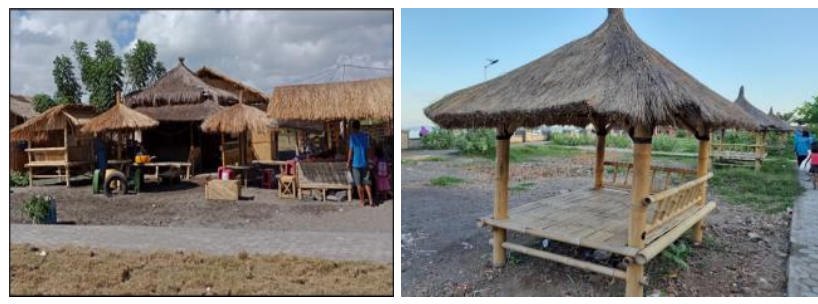

Gambar 1. Wisata Pantai Lungkak

Keunikan dari Wisata Pantai Lungkak, selain memiliki hamparan pasir hitam yang landai, para wisatawan dapat menikmati permainan ombak kecil yang hendak bertepi. Beberapa gili indah yang tidak jauh dari pantai ini tampil mempesona dengan beragam karakter. Demikian pula dengan aktifitas perahu nelayan yang sedang sibuk di tengah laut turut menyegarkan padangan mata bila kita berdiri di tepi pantai ni. Deretan rumah apung yang setia menampung bibit-bibit udang lobster hingga besar menjadi pemandangan klasik dari pantai yang berair jernih ini. Inilah keindahan pesisir pantai yang dapat diraih bila kita mengunjunginya.

\section{Wisata Hutan Bakau (Mangrove)}

Hutan bakau atau disebut juga hutan mangrove adalah hutan yang tumbuh di air payau,dan dipengaruhi oleh pasang-surut air laut. Hutan ini tumbuh khususnya di tempat- tempat di mana terjadi pelumpuran dan akumulasi bahan organik. Baikdi teluk-teluk yang terlindung dari gempuran ombak, maupun disekitar muara sungai dimana air melambat dan mengendapkan lumpur yang dibawanya dari hulu. Ekosistem hutan bakau bersifat khas, baik karena adanya pelumpuran yang mengakibatkan kurangnya abrasi tanah, salinitas tanahnya yang tinggi, serta mengalami daur penggenangan oleh pasang-surut air laut. Hanya sedikit jenis tumbuhan yang bertahan hidup di tempat semacam ini, dan jenis-jenis ini kebanyakan bersifat khas hutan bakau karena telah melewati proses adaptasi dan evolusi. Tidak terkecuali di Desa Ketapang Raya juga memiliki potensi wisata yang berupa Hutan Bakau (Mangrove). Manurut Idrus et al. (2017) dalam laporan akhir "Konservasi Mangrove Berbasis Institusi Masyarakat Lokal Untuk Mendukung Pengembangan Ekowisata dan Sumber Belajar Biologi Di Pantai Selatan Lombok Timur" meyebutkan baahwa spesies Mangrove yang terdapat Kecamatan Keruak sebanyak 10 spesies, yakni: Avicenia lanata, Avicennia marina, Bruguiera silindrika, Ceriops decandra, Rhizophora mucronata, Rhizophora stylosa,
Rhizopora apiculata, Sonneratia alba, Xylocarpus moluccensis, dan Lumnitzera rasemosa.

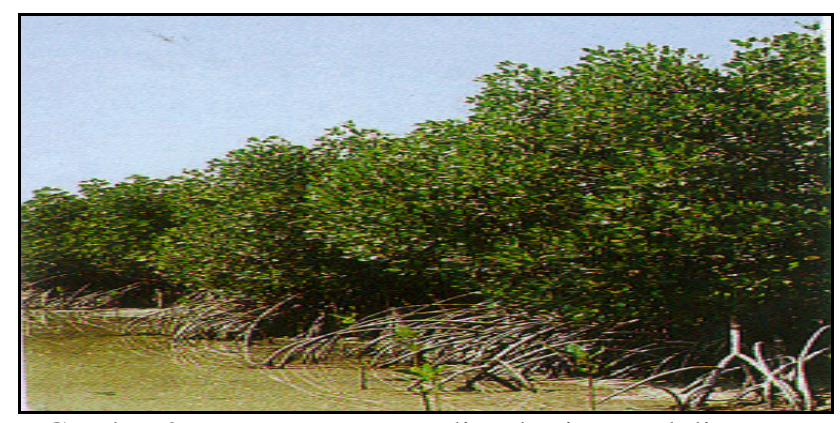

Gambar 2. Hutan Mangrove di Lokasi Pengabdian

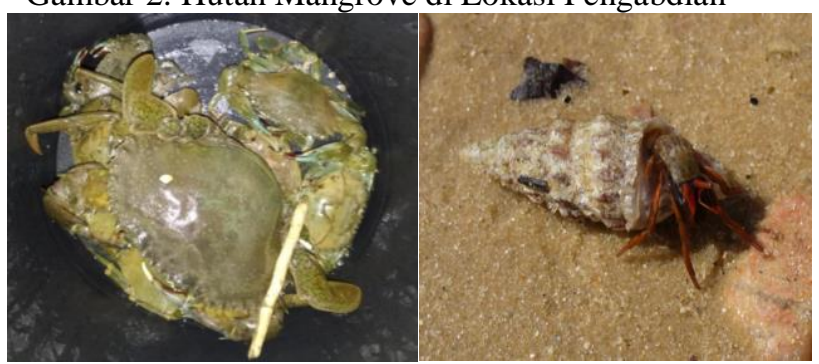

(Kepiting Oranye) (Kelomang Mangrove)

Gambar 3. Biota Asosiasi Mangrove

\section{Wisata Padang Lamun}

Padang lamun adalah ekosistem khas laut dangkal di perairan dan bersubstrat pasir, lamun merupakan sekelompok tumbuhan anggota bangsa Alismatales yang beradaptasi di air asin. Padang lamun hanya dapat terbentuk pada perairan laut dangkal (kurang dari tiga meter) namun dasarnya tidak pernah terbuka dari perairan (selalu tergenang). Ia dapat dianggap sebagai bagian dari ekosistem mangrove, walaupun padang lamun dapat berdiri sendiri. Padang lamun juga dapat dilihat sebagai ekosistem antara ekosistem mangrove dan terumbu karang. Pada suatu kondisi, padang lamun membentuk suatu komunitas yang merupakan habitat bagi berbagai jenis hewan laut. Komunitas lamun ini juga dapat memperlambat gerakan air, bahkan ada juga jenis lamun yang dapat dikonsumsi bagi penduduk sekitar pantai.Keberadaan ekosistem padang lamun masih belum banyak dikenal para masyarakat umum maupun akademisi, jika dibandingkan dengan ekosistem lain seperti terumbu karang dan mangrove. Meskipun diantara ekosistem-ekosistem tersebut di kawasan pesisir merupakan satu kesatuan sistem dalam menjalankan fungsi ekologisnya. 


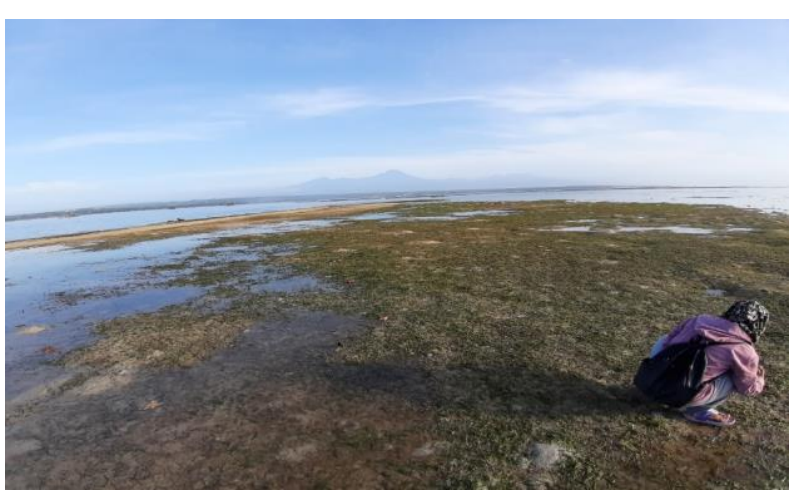

Gambar 4. Pasir Hitam pantai Lungkak

\section{Wisata Pulau Pasir}

Terdapat banyak keunikan dari Lombok, sehingga Lombok menjadi tempat wisata paling menarik. di Kabupaten Lombok Timur khususnya di Desa Ketapang Raya ada banyak sekali objek wisata potensial yang belum di ekspose atau terpublikasikan ke khalayak ramai mulai dari pantai, hutan bakau, padang lamun hingga pulau pasir atau yang biasa disebut Gili Pasir yang sangat unik di tengah lautan. Umumnya, kita tentu sering melihat pulau kecil yang ditumbuhi dengan pepohonan atau bagaikan perbukitan, tapi kali ini anda bisa melihat pulau pasir yang hanya dihampari dengan pasir putih, tanpa pohon atau bahkan warung penjual makanan.

Pulau ini memberikan keunikan tersendiri sebagai pulau pasir lombok di tengah lautan. Pulau ini bisa terlihat di tengah-tengah laut karena muncul saat air surut, sehingga tidak ada pepohonan yang tumbuh di pulau cantik ini. Akses menuju ke pulau pasir ini menggunakan perahu-perahu nelayan yang disewa oleh wisatawan dengan kisaran harga Rp. 25.000 sampai dengan Rp. 30.000 per orang. Keindahan pulau pasir ini semakin terlihat apabila lautan sedang surut sehingga hamparan pasir yang ada di pulau kecil ini makin terlihat dan mempesona. Wisatawan biasanya melakukan aktifitas berftoto bersama atau melakukan swafoto (selfie) di pulau pasir ini. Selain kegiatan berfoto hal lain yang juga dapat dilakukan yaitu snorkeling atau bahkan diving (menyelam). Namun untuk kedua aktifitas tersebut disarankan menggunakan pemandu atau instruktur yang berkompeten, karena arus laut yang terbilang cukup kencang. Sehingga apabila dilakukan oleh pribadi-pribadi yang awam tentang menyelam maka akan berbahaya.

\section{Wisata Keramba Jaring Apung (KJA)}

Keramba Jaring Apung (KJA) adalah sarana pemeliharaan ikan atau biota air yang mengapung diatas air. Tujuan digunakannya KJA ini dikarenakan keramba akan tetap stabil walau ombak besar, karena rangka dari konstruksinya adalah rangkaian dari kubus-kubus apung yang mengikat satu sama laim, sehingga sangat kuat, stabil dan tahan lama. Keramba Jaring Apung (KJA) ini dapat meminimalisir kerusakan lingkungan khususnya kerusakan laut karena aktifitas nelayan. Hal ini dikarenakan semakin banyak ikan yang di tangkarkan maka aktifitas melaut nelayan akan berkurang dan juga kegiatan menangkap ikan di laut dapat dilakukan dengan cara yang lebih baik tanpa menggunakan alat-alat dan bahan yang dapat merusak ekosistem laut. KJA ini selain bernilai dan berfungsi ekonomis juga memiliki daya tarik pariwisata bahari karena dengan adanya KJA ini maka ada banyak biota laut yang dipelihara disana sehingga dapat menarik perhatian wisatawan untuk mengunjunginya sehingga KJA yang berada di Desa Ketapang Raya ini perlu di ekspose dan dilestarikan agar tetap bermanfaat untuk masyarakat baik di sektor perikanan atau pariwisata.

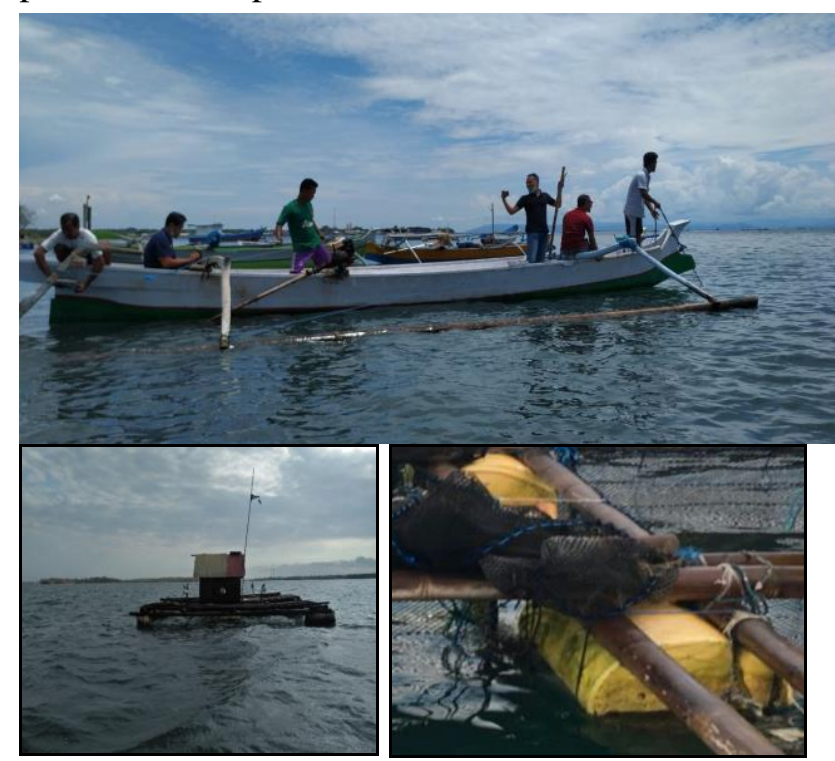

Gambar 5. Ketua LPPM dan Tim Menuju Lokasi Kramba Apung sebagai objeks wisata

Pengembangan ekowisata di lokasi sasaran pengabdian ini memiliki aspek produk inovasi teknologi berkaitan dengan dimensi pemasaran objek ekowisata melalui medsos (media social), dalam bentuk website, dan portopolio tiap obyek ekowisata. Ekowisata berbasis sumber daya alam 
local memiliki prospek yang potensial sesuai dengan minat wisata yang lebih pada keaslian alam. Berkaitan dengan hal ini, lokasi pengabdian memiliki potensi obyek wisata alam yang cukup potensil dikembangkan sebagai obyek wisata.

\section{Metode}

\section{a. Persiapan}

Rencana program pengabdian pada masyarakat di Desa Ketapang Raya tentang pengembangan objek wisata baru sebagai sumber matapencaharaian masyarakat berbasis ekowisata, dalam ha ini TIM pengabdian mepersiapkan beberapa hal yang meliputi materi, konsoidasi dengan pemerintah desa, mitra dan masyarakat sebagai kelompok sasasaran dari kegiatan pengabdian pada masyarakat.

\section{b. Pelaksanaan}

Pengembangan ekowisata di Desa Desa Ketapang Raya berdasarkan solusi dan permasalahan seperti yang telah diuraikan di atas membutuhkan metode pelaksanaan yang relevan. Beberapa metode yang digunakan adalah:

1. Sosialisasi, pada tahap ini Tim mensosialisaikan tema program pada pemerintah Desa, tokoh masyarakat dan stakehoulder lainnya. Metode yang digunakan adalah diskusi. Tujuan pada program sosialisai adalah untuk memperoleh pemahaman yang sama tentang pentingnya pengembangan ekowisata sebagai sumber matapencaharaian berkelanjutan masyarakat di Desa Ketapang Raya. Selain itu disampaikan luaran yang perlu dicapai dari tipa solusi permasalahan.

2. Metode Pelatihan untuk pelatih (Training of Trainer), materi terdiri dari empat bagian yang terdiri dari: (a) langkah-langkah yaitu uraian yang menjelaskan langkah demi langkah yang dapat dilakukan oleh fasilitator dalam memfasilitasi kegiatan pelatihan pada tiap program, (b). bahan bacaan adalah materi bacaan yang dapat dijadikan referensi bagi fasilitator atau pelatih mengenai isi materi yang akan disampaikan dan (c) lembar kegiatan yang merupakan lembar aktivitas yang digunakan peserta dalam proses pembelajaran dan slide presentasi.
3. Fokus Group Diskusi (FGD) adalah metode yang digunakan berdasarkan relevansi tiap solusi, hal ini sangat penting untuk memperoleh informasi mengenai beberapa pertanyaan tentang bagaiamana dan mengapa kita butuhkan ekowisata sebagai sumber matapencaharian yang berkelanjutan bagai masyarakat di Desa Ketapang Raya.

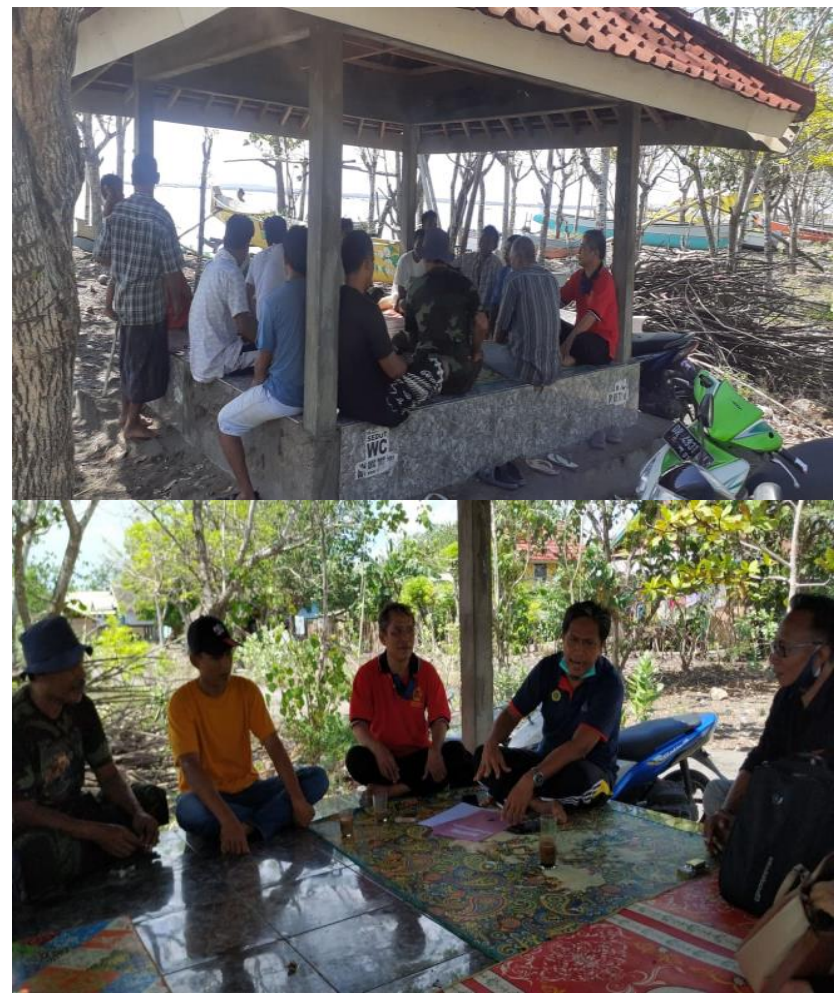

Gambar 6. Sosialisasi Program Pengabdian

\section{Hasil dan Pembahasan}

\section{Analisis Hasil}

Ekowisata atau Ekoturisme merupakan suatu kategori rekreasi yang melibatkan sejumlah orang untuk mengunjungi suatu tempat dan membelanjakan seluruh atau sebagian uangnya demi memperoleh pengalaman berinteraksi dengan lingkungan. Ekowisata meningkat pesat di banyak negara berkembang karena orang ingin menyaksikan dan merasakan sendiri keanekaragaman tropika. Ekoturisme adalah hal tentang menciptakan dan memuaskan suatu keinginan akan alam, tentang mengeksploitasi potensi wisata untuk konservasi dan pembangunan dan tentang mencegah dampak negatifnya terhadap ekologi, budaya dan keindahan. Seiring dengan 
semakin berkembangnya niat konservasi dan peningkatan kesejahteraan masyarakat, maka lahirnya definisi baru mengenai Ekowisata, yaitu: suatu bentuk perjalanan wisata ke area alami yang dilakukan dengan tujuan mengkonservasi lingkungan dan melestarikan kehidupan dan kesejahteraan penduduk setempat. Definisi terbaru dari ekowisata adalah wisata berbasis pada alam dengan menyertakan aspek pendidikan dan interpretasi terhadap lingkungan alami dan budaya masyarakat dengan pengelolaan kelestarian ekologis.

Ekowisata harus dipahami melalui dua sisi yaitu ekowisata dari segi konsep dan ekowisata dari segi pasar. Selanjutnya ekowisata dari segi Konsep Ekowisata merupakan pariwisata bertanggung jawab dilakukan pada tempat tempat alami, serta memberi kontribusi terhadap kelestarian alam dan peningkatan kesejahteraan masyarakat setempat. Selaian itu, ekowisata merupakan konsep pengembangan pariwisata yang berkelanjutan yang bertujuan untuk mendukung upaya-upaya pelestarian lingkungan (alam dan budaya) dan meningkatkan partisipasi masyarakat dalam pengelolaan, sehingga memberikan manfaat ekonomi kepada masyarakat setempat.

Ekowisata memiliki banyak definisi yang seluruhnya berprinsip pada pariwisata yang kegiatannya mengacu pada beberapa manfaat yaitu: (a) memberikan pengalaman dan pendidikan kepada wisatawan yang dapat meningkatkan pemahaman dan apresiasi terhadap daerah tujuan wisata yang dikunjunginya. Pendidikan diberikan melalui pemahaman akan pentingnya pelestarian lingkungan, sedangkan pengalaman diberikan melalui kegiatan wisata yang kreatif disertai dengan pengalaman yang prima, (b) memperkecil dampak negatif yang bisa merusak karakteristik lingkungan dan kebudayaan pada daerah yang dikunjungi (c) mengikutsertakan masyarakat dalam pengelolaan dan pelaksanaannya, (d) memberikan keuntungan ekonomi terutama kepada masyarakat lokal, untuk itu, kegiatan ekowisata harus bersifat profit (menguntungkan) dan (e) dapat terus bertahan dan berkelanjutan.

Kata ekowisata selalu mengacu pada bentuk kegiatan wisata yang mendukung pelestarian. Ekowisata semakin berkembang tidak hanya sebagai konsep tapi juga sebagai produk wisata (misalnya: paket wisata) dengan konsep "eko" atau "hijau" menjadi trend di pasar wisata.
Konsep "kembali ke alam" cenderung dipilih oleh sebagian besar konsumen yang mulai peduli akan langkah pelestarian dan keinginan untuk berpatisipasi pada daerah tujuan wisata yang dikunjungi. Akomodasi, atraksi wisata maupun produk wisata lainnya yang menawarkan konsep kembali ke alam semakin diminati oleh pasar. Namun sebaliknya para penyedia jasa pariwisata, daerah tujuan wisata maupun pemerintah setempat yang berorientasi pada ekowisata harus memiliki kebijakan dan program tersendiri terkait pelestarian lingkungan, budaya setempat dan manfaat kepada masyarakat lokal. Karena pada banyak tempat, produk-produk wisata yang dijual kebanyakan menyematkan kata "eko" dan "kembali ke alam" hanya sebagai 9 label untuk menarik konsumen, namun tidak disertai dengan semangat melestarikan atau melibatkan masyarakat setempat dalam produk wisata tersebut.

Desa Ketapang Raya salah satu desa pantai dengan jumlah nelayan kecil sebesar $50 \%$ dari total jumlah penduduk sebanyak 4376. Nelayan skala kecil ini telah mengembangkan budidaya untuk mengatasi masalah ekonomi keluarga, sebagai akibat dari hasil tangkapan ikan yang sudah tidak menentu. Potensi lingkungan laut di Desa Ketapang Raya cukup mendukung untuk kegiatan budidaya ikan dan biota laut lainnya yang bernilai ekonomi. Pada saat ini wilayah pesisir di sekitar Desa Ketapang Raya telah menjadi tujuan wisata baru dan Desa Ketapang Raya telah mengembangkan wisata pantai sebagai objek wisata sejak tahun 2016. Dalam hal ini untuk mendukung keberlanjutan pariwisata yang telah menjadi sumber matapencaharian baru masyarakat di Desa Ketapang Raya dilaksanakan dengan prinsip menjaga kelestarian lingkungan dan hal ini sesuai dengan prinsip budidaya yang dikembangkan oleh kelompok nelayan pembudidaya yaitu budidaya ramah lingkungan. Budidaya ramah lingkungan yang telah menjadi objek wisata dan berdampak positif untuk meningkatkan pendapatan pembudidaya dan untuk pengembangan dan keberlanjutannya berbasis ekowisata. Beberapa permasalahan berkaitan dengan kelompok pembudidaya untuk mengembangkan budidaya ramah lingkungan berbasis ekowisata di antaranya adalah: (1) belum memiliki manajemen pengelolaan budidaya ramah lingkungan berbais ekowisata dan (2) budidaya ramah lingkungan sebagai objek 
wisata baru masih menggunakan promosi secara konvensional.

Bentuk pariwisata yang dapat memenuhi hal tersebut adalah kegiatan ekowisata yang dikembangkan di Desa Ketapang Raya. Ekowisata ini secara umum menitikberatkan peran aktif masyarakat atau komunitas. Hal tersebut didasarkan pada kenyataan bahwa masyarakat memiliki pengetahuan tentang alam serta budaya yang menjadi potensi dan nilai jual. Dengan adanya perkembangan pariwisata di Desa Ketapang Raya, diharapkan dapat menyerap banyak tenaga kerja dan meningkatkan kesejahteraan masyarakat. Tenaga kerja yang terserap diharapkan dapat mencapai hingga $75 \%$ dari usia produktif masyarakat yang belum memiliki pekerjaan atau bahkan yang beralih dari pekerjaannya sebagai nelayan menjadi pelaku usaha di bidang pariwisata. Tenaga kerja yang terserap dapat menjadi pengelola tempat wisata, menyewakan peralatan yang berkaitan dengan tempat wisata atau bahkan menjadi pemandu wisata di tempat tersebut.

Sektor pariwisata yang terbatas hanya pada budidaya ramah lingkungan juga tidak menjamin seutuhnya bisa menjadi sumber pendapatan masyarakat selain melaut. Sehingga potensi pariwisata di Desa Ketapang Raya perlu dikembangkan lebih jauh lagi agar bisa menjadi mata pencaharian atau sumber pendapatan masyarakat Desa Ketapang Raya. Jika pengelolaan pariwisata dilakukan secara bijak, tepat, bersifat ramah lingkungan dan berkelanjutan, dengan keterlibatan masyarakat nyatanya dapat menambah penghasilan serta mendorong masyarakat lebih menjagasumberdayaalamdanlingkungannya.Kondis i ini menjadikan pariwisata memberi peluang manfaat bagi peningkatan ekonomi masyarakat dan pelestarian alam. Bentuk pariwisata yang dapat memenuhi hal tersebut adalah kegiatan ekowisata yang dikembangkan di Desa Ketapang Raya. Ekowisata ini secara umum menitikberatkan peran aktif masyarakat atau komunitas. Hal tersebut didasarkan pada kenyataan bahwa masyarakat memiliki pengetahuan tentang alam serta budaya yang menjadi potensi dan nilai jual. Perkembangan pariwisata di Desa Ketapang Raya, diharapkan dapat menyerap banyak tenaga kerja dan meningkatkan kesejahteraan masyarakat. Tenaga kerja yang terserap diharapkan dapat mencapai hingga $75 \%$ dari usia produktif masyarakat yang belum memiliki pekerjaan atau bahkan yang beralih dari pekerjaannya sebagai nelayan menjadi pelaku usaha di bidang pariwisata. Tenaga kerja yang terserap dapat menjadi pengelola tempat wisata, menyewakan peralatan yang berkaitan dengan tempat wisata atau bahkan menjadi pemandu wisata di tempat tersebut.

Objekvitas dan rasionalitas dari program pemberdayaan masyarakat pesisir melalui pengembangan objek wisata baru berbasis ekowisata ini didasarkan atas beberapa hal yaitu: (1) aspek ekonomi nelayan atau masyarakat memiliki tambahan sumber pendapatan dari jasa wisata dan sarana pariwisata (2) aspek ingkungan, nelayan, masyarakat sekitar, maupun stake holder pariwisata akan menjaga kelestarian lingkungannya , (3) aspek sosial, antar masyarakat akan terbentuk sistem sosial yang lebih akomodatif dalam menjaga kerentanan sosial masyarakat dan (4) aspek manajemen, masyarakat dan pelaku pariwisata mampu mengelola tempat wisata yang berkelanjutan.

Keramba Jaring Apung (KJA) adalah sarana pemeliharaan ikan atau biota air yang mengapung diatas air. Aktivitas budidaya laut dalam bentuk KJA ini dapat dikembangkan menjadi salah satu objek wisata baru di Desa Ketapang Raya. Hal ini didasarkan beradasrkan hasil observasi menunjukkan bahwa budaya laut sudah menjadi pilihan matapencaharaian masayarakat di Desa Ketapang Raya. Perkembangan jumlah pembudidaya dari masyarakat di Desa Ketapang Raya terus meningkat dari hasil observasi menunjukan bahwa saat ini telah meningkat yaitu dari 5 pembudidaya pada tahun 2016 dan pada tahuan 2016 menjadi 30 pembudidaya. Selain itu hal positip yang berkaitan dengan wisata pada KJA adalah kenyaman untuk menikmati suasanan laut dan keragaman jenis biota yang ada pada KJA dan sekitar KJA, mudah diakses dengan mmengguanakan perahu nelayan. Hal ini yang menyebabakan KJA memiliki daya tarik pariwisata bahari karena dengan adanya KJA ini maka ada banyak biota laut yang dipelihara disana sehingga dapat menarik perhatian wisatawan untuk mengunjunginya.

Program pengabdian ini bertujuan untuk menambah wawasan masyarakat luas tentang apa itu Keramba Jaring Apung, manfaatnya untuk masyarakat dan dapat mempromosikan Keramba Jaring Apung ini sebagai tempat wisata untuk memberikan inovasi terbaru dalam bidang 
pariwisata dimana tidak terbatas pada pantai atau taman hiburan semata. Jenis wisata pada Keramba Jaring Apung dan disekitaraya berdasarkan hasil observasi dan diskusi dengan pembudidaya yang utama adalah sebagai tempat memancing. Selanjutnaya permasalahan pada pengebangan wisata dengan sarana KJA ini adalah belum ada promosi dan standar pengembangan wisata sebagai panduan wisatawan. Metode pelaksanaan dalam pengembangan obyek wisata KJA yaitu dengan melakukan observasi secara langsung untuk mengetahui kondisi, fauna yang ada di dalamnya, serta potensi yang dapat di kembangkan. Hasil dari kegiatan pengembangan obyek wisata KJA ini adalah berupa prototype obyek wisata KJA. Dalam prototype ini memuat tentang manfaat, ciri-ciri KJA, ekosistem, flora dan fauna, fungsi, dan luas wilayah KJA, upaya pelestarian, dan potensi wisata yang dapat dikembangkan. Berdasarkan hasil kegiatan yang telah dilakukan untuk pengembangan wisata berbasis budidaya ramah lingkungan d Desa Ketapang Raya diantaranya adalah:

1. Penguatan konsep ekowisata kelompok pembudidaya, jasa wisata dari aktivitas budidaya ramah lingkungan di parairan pesisir Desa Ketapang Raya adalah produk sekunder. Meskipun demikian memiliki pengaruh positif terhadap para nelayan sebagai pelaku budidaya diantaranya adalah: (a) sosial, dari sisi ini nelayan sebagai pelaku budidaya memiliki relasi sosial yang luas dengan banyak komunitas yang berasal dari berbagai daerah, (b) ekonomi, nilai ekonomi langsung yang diperoleh oleh pembudidaya adalah jasa transportasi dari para pemancing yang memanfaatkan sarana KJA sebagai lokasi pemancingan. Oleh karena itu dibutuhakan pemahaman yang memadai tentang ekowisata untuk keberlanjutan produk sekunder dari usaha budidaya nelayan di Desa Ketapang Raya. Hasil diskusi dengan para pelaku budidaya dan para wasatawan pemancing pada tatataran aplikasi sebenarnya mereka telah menerapakan prinsip-prinsip ekowisata yang berkaitan dengan keamanan lingkungan dari aktiviatas yang dapat menyebabkan sumberdaya ikan sebagai target pemancing tidak hilang dari sekitar areal budidaya. Salah satu bentuknya adalah mereka tidak membuang sampah anorganik yang berupa palstik pada saat melaksanakan aktivitas pemancingan bagi wisatawan pemancing dan pelaku budidaya menjaga areal sekitar budidaya dari paraktekpraktek yang tidak ramah lingkungan dari masyarakat seperti penggunaan potassium dan bom ikan. Namun demikian secara konseptual mereka belum memahami secara lebih komprehensip berkaitan dengan manfaat ekowisata dari aspek pelestarian lingkungan untuk pemanfaatan yang berkelanjutan dan nilai ekowisata terhadap pendidikan bagi generasi muda. Dalam hal ini Tim pengabdian pada masyarakat melalui diskusi mendalam dengan para wisatawan dan pelaku budidaya berkaitan dengan ke dua aspek tersebut dalam perpspktif ekowisata. Hasilnya adalah mereka dapat mengerti dan menyetakan bahwa dari semua pembudidaya membutuhkan kesepahaman untuk menjaga lingkungan dan mereka menyatakan menjaga lingkungan tidak saja untuk kepentingan wisata tetapi telah terbukti dengan menjaga lingkungan jumlah ikan semakai banyak di sekiatar areal budidaya. Hal ini dibuktikan dengan meningkatnya pendapatan nelayan pemancing dan mencari ikan hanya di sekitar perairan budidaya.

2. Promosi ekowisata budidaya ramah lingkungan, sarana budidaya yang telah di kenal olah masyarakat dan telah dimanfaatkan sebagai sarana pemancaingan adalah salah satu bentuk promosi secara konvensional yang berlansung saat ini. Oleh karena itu objek lain yang belum dipromosikan perlu di munculkan untuk menambah objek wiasata budidaya ramah lingkungan. Hasil observasi objek yang dapat dipromosikan adalah keragaman jenis budidaya yang ada pada kolam budidaya dan waktu yang paling nyaman untuk menikmati keindahan laut dari KJA. Hasil diskusi dengan kelompok pembudidaya jenis dan karagaman jenis biota yang dibudidaya beruapa lobster dan ikan sering menjadi perhatian para wiasatawan yang berkunjung ke objek wisata lain seperti wisata pantai. Selanjutnya, dari hasil diskusi dengan pembudidaya waktu yang paling nyaman untuk berkunjung ke lokasi budidaya adalah pada pagi hari yaitu antara jam 08.00 - jam 10.00, pada waktu pagi hari suasana air laut masih tenang dan belum ada gelombang besar, sehingga cukup nyaman untuk menikmati suasana laut yang indah. Namun demikian, mereka para pembudidaya dengan kemampuan tidak dapat mempromosikan objek baru yang ada pada 
wisata budidaya ramah lingkungan KJA. Oleh karena itu, dari hasil analisis dibutuhkan pihak lain untuk melakukan promosi untuk membantu pengembanagan wisata budidaya ramah laingkungan. Hasil diskusi dengan para pembudidaya pihak lain yang relevan dilibatkan adalah organisasi pemuda di Desa Ketapang Raya di bawah koordinasi kepala desa.

3. Kelembagaan kelompok pembudidaya, penguatan kapasitas kelembagaan kelompok pembudidaya adalah bagian penting untuk pengembangan wisata budidaya ramah lingkungan di Desa Ketapang Raya. Hal ini didasarkan atas bertambahnya produk budidaya dari aspek parawaisata. Hasil analisis menunjukan bahwa anggota kelompok pembudidaya memiliki tingkat pendidikan sebagain besar tidak tamat pendidikan dasar. Oleh karena itu untuk meningkatkan kapasitas kelembagaan dapat dilakukan melalui dua cara yaitu; (1). pendampingan pada kelompok pembudidaya secara berkelanjutan agar mereka mampu mengorganisasikan kebutuhankebutuhan yang berkaitan dengan produk langsung budidaya dan produk sekunder dari parawisata, dan (2) pelatihan pada kelompok masyarakat yang memiliki tingkat pendidikan dan minimal memiliki pendidikan SLTA sebagai pelatih untuk keleompok pembudidaya di Desa Ketapang Raya.

\section{Faktor Pendorong}

Pengembangan wiasata budidaya ramah lingkungan pada KJA di Desa Ketapang Raya memiliki nilai sosial dan ekonomi yang secara langsung dapat memberikan manfaat pada para pelaku budidaya. Hasil analisi dari selama proses pengabdian pada masyarakat di peroleh beberapa hal positif sebagai faktor pendorong untuk pengembangan wisata budidaya ramah lingkungan sebagai objek wisata baru yaitu:

1. Pengalaman, pembudidaya ramah lingkungan di Desa Ketapang Raya, secara praktis memiliki pengalaman dalam pemanfaatan sarana KJA untuk para pemancing yang datang dari luar Desa Ketapang Raya. Meskipun hal ini belum diasosiasikan dengan asepk wisata tetapi nilainya yang dikembangkan adalah mengandung unsur wiasata yang sangat bermanfaat dari sisi penambahan pendapatan pelaku budidaya dan para pemancing tidak mengganggu keamanan budidaya. Hal ini dapat menjadi faktor pendorong yang cukup relevan untuk pengembangan wisata budidaya ramah lingkungan di Desa Ketapang Raya.

2. Lingkungan, Perairan laut di Desa Ketapang Raya memiliki karakteristik perairan semi terbuka, meskipun demikian di bagian depan terlindung oleh dua pulau kecil yaitu Gili Maringkik dan Gili Kere.

3. Akses, selaian keamanan akses ke lokasi budidaya cukup mudah sebagai objek wisata, diamana dapat ditempuh dalam waktu 5 menit dengan menggunakan perahu pemilik budidaya.

4. Perkembangan wisata di Desa Ketapang Raya, wisata di desa ini mulai berkembang pada tahun 2016 dan saat ini perkembamgannya sudah cukup pesat dilihat dari sejumlah fasilitas berupa kape dan sarana umum. Namun demikian jenis wisata yang berkembang adalah masih wisata pantai dan di lain pihak masih banyak objek wiasata baru dari Desa Ketapang Raya yang belum dikembangkan. Salah satu yang memiliki potensi untuk dikembangkan adalah wisata budidaya ramah lingkungan yang berbasis ekowisata. .

5. Dukungan, Pemerintah Desa Ketapang Raya memberikan respon yang cukup positif untuk pengebangan objek wiasata baru yaitu wisata budidaya ramah lingkungan yang dapat menjadi komplementer dari rencana desa untuk mengembangkan wisata koliner khas hasil laut di Desa Ketapang Raya. Selain ini mmenurut Kepala Desa di Desa Ketapang Raya dalam waktu dekat akan dikembangkan wisata koliner rumah makan apung yang dapat menjadi komplementer dari wisata budidaya ramah lingkungan yang memiliki potensi cukup baik di perairan Desa Ketapang Raya.

\section{Faktor Penghambat}

Pengembangan wisata budidaya ramah lingkungan berbaisis ekowisata di Desa Ketapang Raya memiliki nilai yang cukup positif dari aspek ekonomi, sosial, pendidikan dan kelestarian lingkungan. Namun demikian, selama proses kegiatan pengabdian pada masyarakat ditemukan beberapa hal yang menjadi kendala dan membutuhkan solusi. Beberapa kendala adalah tingkat pendidikan pembudidaya yang rata-rata tidak tamat SD membutuhkan pendampingan secara berkala dan berkelanjutan untuk meningkatkan kapasitasnya dalam mengorganisasikan 
keberlanjutan produk dalam bentuk hasil budidaya dan jasa wisata. Selain itu, ditemukan kendala yang bersifat temporal yaitu waktu kunjungan wisatawan yang sangat terbatas, meskipun dapat menjadi keunikan dari wisata budidaya ramah lingkungan berbasis ekowisata di Desa Ketapang Raya.

\section{Kesimpulan}

Kegiatan pengabdian ini memiliki manfaat diantaranya: 1) bagi masyarakat, memperoleh mata pencaharian tambahan yang memiliki kontribusi untuk ketahanan ekonomi keluarga, 2) bagi Lingkungan, khususnya ekosistem Mangrove dan Padang Lamun dapat berkelanjutan fungsi ekologinya untuk kelestarian biota laut dan lingkunyannya, dan 3) bagi Pemerintah khususnys Pemerintah Desa dapat menjadikan model ekowisata untuk peningkatan kesadaran social dan partisipasi Masyarakat dalam menjaga ketertiban Masyarakat.

\section{Ucapan Terima Kasih}

Penulis mengucapkan terima kasih kepada Rektor Universitas Mataram yang telah memberi dukungan finansial terhadap pengabdian ini.

\section{Daftar Pustaka}

Agil, Al.I., Syukur, A dan Zulkifli, L. 2017. Konservasi Mangrove melalui Pendekatan Intitusi Masyarakat Lokal untuk Pengembangan Ekowisata dan Sumber Belajar Biologi di Pantai Lombok Timur Selatan. Laporan Peneitian PPM Universitas Mataram.

Agil, Al.I., Syukur, A dan Zulkifli, L. 2017. Konservasi Mangrove melalui Pendekatan Intitusi Masyarakat Lokal untuk Pengembangan Ekowisata dan Sumber Belajar Biologi di Pantai Lombok Timur Selatan. Laporan Peneitian PPM Universitas Mataram.

Laporan KKN Tematik Universitas Mataram 2018. Pemberdayaan Masyarakat Pesisir Melalui Pengembangan Objek Wisata Baru Berbasis Ekowisata di Desa Ketapang Raya Kecamatan Keruak, 